\title{
Bat flies (Diptera: Streblidae, Nycteribiidae) parasitic on bats (Mammalia: Chiroptera) at Parque Estadual da Cantareira, São Paulo, Brazil: parasitism rates and host-parasite associations
}

\author{
Patrícia Beloto Bertola/ ${ }^{+}$, Caroline Cotrim Aires*, Sandra Elisa Favorito**, \\ Gustavo Graciolli***, Marcos Amaku/ ${ }^{+}$, Ricardo Pinto-da-Rocha****
}

\begin{abstract}
Laboratório de Epidemiologia e Bioestatística, Faculdade de Medicina Veterinária e Zootecnia, Universidade de São Paulo, Cidade Universitária, Av. Prof. Orlando Marques de Paiva 87, 05508-000, São Paulo, SP, Brasil *Laboratório de Biologia Evolutiva e Conservação, Instituto de Biociências, USP, São Paulo, SP, Brasil **Laboratório de Biodiversidade, Universidade Bandeirante de São Paulo, São Paulo, SP, Brasil ****Departamento de Zoologia, Universidade Federal do Paraná, Curitiba, PR, Brasil *****Departamento de Zoologia, Instituto de Biociências, USP, São Paulo, SP, Brasil
\end{abstract}

A total of 443 bat flies belonging to the families Nycteribiidae and Strelidae, were collected on 22 species of bats (Molossidae, Phyllostomidae, and Vespertilionidae) from Parque Estadual da Cantareira (São Paulo, Brazil), between January, 2000 and January, 2001. Eighteen new occurrences of bat flies were recorded on Anoura geoffroyi (Anastrebla caudiferae), Glossophaga soricina (A. caudiferae), Sturnira lilium (Trichobius phyllostomae, T. furmani, and Paraeuctenodes similis), Artibeus lituratus (A. caudiferae), A. fimbriatus (Megistopoda proxima), A. obscurus (Metelasmus pseudopterus), Myotis nigricans (M. proxima, M. aranea, Paratrichobius longicrus), M. ruber (Anatrichobius passosi, Joblingia sp.), M. levis (A. passosi), M. albescens (A. passosi, Basilia andersoni), and Histiotus velatus (M. aranea). Seven new occurrences were recorded for the state of São Paulo, increasing the range for $\mathrm{T}$. tiptoni, T. furmani, M. proxima, Aspidoptera falcata, A. caudiferae, A. modestini and B. andersoni. The relationships between parasitism and host sex, reproductive stage, age hyperparasitism by fungi are discussed.

Key words: Nycteribiidae - Streblidae - bat flies - bats - São Paulo - Brazil

The arthropod ectoparasites of bats belong to the Siphonaptera, Diptera, Hemiptera, Dermaptera, and Acari (ticks and mites) but they are not necessarily restricted to bats (Whitaker 1998). According to Marshall (1982), 687 bat ectoparasite insect species are known, belonging to the Dermaptera, Hemiptera, Diptera, and Siphonaptera orders. Six families from these four orders are restricted to bats.

The Diptera includes two families that are exclusively bat ectoparasites, Nycteribiidae and Streblidae (Allen 1967). Both families present adenotrophic viviparity, i.e. all larval stages develop entirely within the genital chamber of the female, where the larvae are nourished. They pupate immediately after leaving de genital chamber (Bequart 1940). The adults present a mean length of $5 \mathrm{~mm}$ and are all obligate hematophagous.

The Nycteribiidae occur primarily in the Old World, and present a high degree of specialization, differing greatly from other Dipteran both in morphology and behavior (Guimarães \& D'Andretta 1956). They are wingless and flight muscles are atrophied, resulting in a small thorax comparing with the abdomen, and the legs and head present dorsal insertions in the thorax (Peterson \& Wenzel 1987).

The Streblidae have a greater morphological variation and morphological changes are not as marked as in

Financial support: Uniban Foundation

${ }^{+}$Corresponding author. E-mail: patriciabertola@ hotmail.com Received 2 July 2004

Accepted 3 December 2004
Nycteribiidae. The wings can be normal, reduced or absent, the eyes can be small or absent, the body can be flattened laterally or dorso-ventrally, the legs can vary from short and strong to long and thin (Whitaker 1988). The majority of the species are found in tropical and subtropical regions, with few species found in temperate regions (Whitaker 1988).

According to Fritz (1983), bat ectoparasites knowledge offers important information to understand biological, systematic, and phylogenetic aspects of the hosts, and also to clarify epidemiological aspects of the transmission of some diseases among bats.

In South America, several studies have been done on the taxonomy of Streblidae and Nycteribiidae (Guimarães \& D'Andretta 1956, Barquez et al. 1991, Claps et al. 1992, Guerrero 1993, 1994a,b, 1995a,b, Autino et al. 1998, 1999, 2000, Graciolli \& Carvalho 2001a,b, Graciolli \& Coelho 2001, Graciolli \& Linardi 2002). However, just a few studies deal with the host-parasits relationship in detail, but they are restricted to a single region, such as the research carried out in the region of Uberaba, Minas Gerais, by Komeno and Linhares (1999) and Linhares and Komeno (2000).

The purpose of this paper was to study the host-parasite relationships, evaluating the influence of sex and reproduction stage of the host on bat fly parasitism rates, and the relationships of the hyperparasitism of the flies by fungi in the chiropterofauna of the Cantareira region.

\section{MATERIALS AND METHODS}

Study area - The Parque Estadual da Cantareira is located between $23^{\circ} 21^{\prime}$ '00'to $23^{\circ} 27^{\prime} 00^{\prime}$ 'S and 46 $29^{\circ}$ '00" to $46^{\circ} 42^{\prime} 00^{\prime \prime} \mathrm{W}$, in the state of São Paulo, Brazil, including 
the municipalities of Caieiras, Mairiporã, Guarulhos, and São Paulo. It is considered the largest urban forest of the world, with a total area of 7916 ha (Negreiros et al. 1974).

According to Rizzini (1979), the Serra da Cantareira vegetation is a remnant of altitudinal Atlantic Rain Forest, defined as a kind of forest that covers the mountain range from 800 to $1700 \mathrm{~m}$. The climate of the region is classified as mesothermic and humid, with no definite dry season. It presents an average annual temperature of $18.2^{\circ} \mathrm{C}$, average annual rainfall of $2104 \mathrm{~mm}$, with the rainy period occuring between October and March and the dry periods between April and September (Negreiros et al. 1974).

Captures - Nine monthly sampling were carried out between February, 2000 and January, 2001, preferably during the Last Quart or New Moon phases. In each sampling, during three nights in each of the sampled areas of the Pedra Grande region, 8 mist nets $(7 \times 3 \mathrm{~m}$ each) were set up from 18 to $24 \mathrm{~h}$, checked each $30 \mathrm{~min}$.

The collected bats were separated in numbered bags. The following data were recorded: time of capture, date and locality, sex, weight, right forearm length, reproductive stage (inactive female, pregnant, pregnant-lactant, lactant, post lactant; inactive male with or without visible scrotum), developmental stage (juvenile, adult, senile), and species.

During each bat inspection, the presence or absence of ectoparasites was recorded. When present, the parasites were individually placed in labelled eppendorf vials containing $70 \%$ ethanol.

Identification and analysis - The identification of the bat flies was made with the aid of a stereomicroscope, according to Graciolli and Carvalho (2001a,b) pictoric identification key as well as by comparison with the material deposited in the Ectoparasite collection of the Museu de Zoologia da Universidade de São Paulo (MZSP).

Flies were identified and sexed. It was not possible to determine the sex of a few specimens due to the damage done to the abdomen during collection.

For each reproductive and developmental stage of the host, the following parasitism rates and relationships, were determined according to Bush et al. (1997): (a) prevalence (number of infested bats)/(number of examined bats); (b) mean abundance (number of ectoparasites)/(number of examined bats); and (c) mean intensity (number of ectoparasites)/(number of infested bats).

Statistical analysis was carried out using Minitab ${ }^{\circledR}$ (Minitab Inc.) and Epi-Info 6.04 (CDC) programs.

In order to verify the statistical significance in the sex ratio of a given ectoparasite species, a comparison test of available proportions, using the above mentioned programs, was carried out. The $\chi^{2}$ test was used to verify the association between the age of the most abundant hosts (Sturnia lilium, Artibeus lituratus, and Carollia perspicillata) for each sex, considering also the reproductive stage and the presence or absence of the most abundant bat flies for each of the hosts (Megistopoda proxima, Paratrichobius longicrus, and Trichobius joblingi, respectively). When the expected value for each of the cell was smaller than 5.0, the exact value of "p" was calculated. To verify the results in the cases where two samples were compared, the comparison test for two samples was also used. The results obtained were similar to those of the $\chi^{2}$ test. The prevalence of hyperparasitism of the flies by fungi and the respective confidence interval of 95\% was estimated based on the exact binomial distribution.

\section{RESULTS AND DISCUSSION}

A total of 591 bats, belonging to 22 species of the families Molossidae, Vespertilionidae, and Phyllostomidae (Subfamilies Phyllostominae, Glossophaginae, Stenodermatinae, Carollinae, Desmodontinae) were captured. The most abundant species were Sturnira lilium Geoffroy, 1810 (42.1\%), Artibeus lituratus Olfers, 1818 (17.2), Carollia perspicillata Linnaeus, 1758 (7.8\%), A. fimbriatus Gray, 1838 (6.2\%), and Myotis nigricans Schinz, $1821(4.7 \%)$.

No bat flies were found on Molossops neglectus Willian \& Genoways, 1980, Eptesicus brasiliensis (Desmaret, 1819), E. diminutus Osgoog, 1915, Myotis riparius Handley, 1960, and Pygoderma bilabiatum Wagner, 1843.

The absence of ectoparasites on E. diminutus and $M$. neglectus could be related to the small collected number of these hosts (Table I). There are no records of ectoparasites on these species in the literature. This could be related to the difficulty in collecting these insectivorous bats with the commonly used capture techniques and also due to fact that occasionally, these species have been misidentified. The efficacy of grooming in these species as of bat flies remover is unknown.

P. bilabiatum and E. brasiliensis, with 14 and 21 captured individuals respectively, were also not infested by flies. However, contrary to the above mentioned species, P. bilabiatum and E. brasiliensis are easily identified and present higher capture numbers than those of the insectivorous bats.

A total of 443 bat flies were found in 218 infested bats. The flies belonged to 11 genera and 17 species of Streblidae (426 specimens) and one genus and two species of Nycteribiidae (17 specimens). The most abundant species were Megistopoda proxima Séguy, 1926 (23.9\%), Paratrichobius longicrus Miranda-Ribeiro, 1907 (16.7\%), Trichobius joblingi Wenzel, 1966 (13.3\%), and Paraeuctenodes similis Wenzel, 1966 (7\%).

The bat flies species mean abundances on the collected Vespertilionidae bat family are Basilia andersoni (0.14), Anatrichobius passosi (0.09), Basilia sp. (0.06), M. proxima (0.04), Joblingia sp. (0.03), M. aranea (0.03), $P$. longicrus (0.01). In the Phyllostomidae bat family the mean abundances are $M$. proxima $(0.21), P$. longicrus $(0.14), T$. joblingi (0.12), $P$. similis (0.06), A. modestini (0.05), $T$. phillostomae (0.04), M. aranea (0.04), Anastreba caudiferae (0.03), Exastinion clovisi (0.03), T. tiptoni (0.02), Aspidopora falcata (0.02), M. pseudopterus (0.01), T. dugesioides (0.01), Trichobius sp. (0.01), and T. furmani and Strebla guajiro were smaller tham 0.01.

Occurrence - Streblidae were represented by 17 species (Table I). Of these, six are new occurrences on hosts, of which two are new for genera and five are new for species of hosts. 
TABLE I

Bat flies collected on bats at Parque Estadual da Cantareira, São Paulo, SP, between February 2000, and January, 2001

\begin{tabular}{|c|c|c|c|c|}
\hline Host & $\mathrm{Nr}$ & Bat flie species & $\mathrm{Nr}$ & Mean abundance \\
\hline \multirow[t]{7}{*}{ Sturnira lilium } & 249 & Megistopoda proxima $^{d}$ & 102 & 0.41 \\
\hline & & Trichobius phillostomae $b / d$ & 19 & 0.07 \\
\hline & & Aspidoptera falcatad & 11 & 0.044 \\
\hline & & Paratrichobius longicrus A & 4 & 0.016 \\
\hline & & Trichobius furmani ${ }^{b} / d \mathrm{~A}$ & 1 & 0.004 \\
\hline & & Trichobius joblingi $\mathrm{A}$ & 1 & 0.004 \\
\hline & & Paraeuctenodes similis ${ }^{b} \mathrm{~A}$ & 1 & 0.004 \\
\hline \multirow[t]{4}{*}{ Artibeus lituratus } & 102 & Paratrichobius longicrus & 63 & 0.61 \\
\hline & & Megistopoda aranea & 2 & 0.02 \\
\hline & & Trichobius sp. A & 2 & 0.02 \\
\hline & & Anastrebla caudiferae ${ }^{b / d} \mathrm{~A}$ & 1 & 0.01 \\
\hline \multirow[t]{6}{*}{ Carollia perspicillata } & 46 & Trichobius joblingi & 57 & 1.24 \\
\hline & & Paraeuctenodes similis & 30 & 0.65 \\
\hline & & Trichobius tiptoni ${ }^{d} \mathrm{~A}$ & 3 & 0.065 \\
\hline & & Strebla guajiro & 2 & 0.04 \\
\hline & & Trichobius sp. & 1 & 0.021 \\
\hline & & Megistopoda proxima ${ }^{d} \mathrm{~A}$ & MP & - \\
\hline \multirow[t]{4}{*}{ Artibeus fimbriatus } & 37 & Megistopoda aranea & 8 & 0.21 \\
\hline & & Megistopoda proxima ${ }^{c} /^{d} \mathrm{~A}$ & 2 & 0.05 \\
\hline & & Paratrichobius longicrus & 2 & 0.054 \\
\hline & & Metelasmos pseudopterus & 2 & 0.05 \\
\hline \multirow{6}{*}{ Myotis nigricans } & 28 & Basilia andersoni ${ }^{d}$ & 10 & 0.35 \\
\hline & & Basilia sp. & 2 & 0.07 \\
\hline & & Basilia sp. & MP & - \\
\hline & & Megistopoda proxima ${ }^{a}{ }^{d} \mathrm{~A}$ & 3 & 0.10 \\
\hline & & Megistopoda aranea $^{a} \mathrm{~A}$ & MP & - \\
\hline & & Paratrichobius longicrus ${ }^{a} \mathrm{~A}$ & 1 & 0.03 \\
\hline Eptesicus brasiliensis & 21 & Non-infested & 0 & 0 \\
\hline \multirow[t]{3}{*}{ Myotis ruber } & 15 & Anatrichobius passosi $^{c}$ & 5 & 0.33 \\
\hline & & Joblingia sp. $^{e}$ & 2 & 0.15 \\
\hline & & Basilia sp. & 1 & 0.06 \\
\hline \multirow[t]{2}{*}{ Desmodus rotundus } & 15 & Trichobius dugesioides & 3 & 0.2 \\
\hline & & Trichobius joblingi & 1 & 0.06 \\
\hline Pygoderma bilabiatum & 14 & Non-infested & 0 & 0 \\
\hline \multirow[t]{2}{*}{ Artibeus obscurus } & 12 & Megistopoda aranea & 11 & 0.91 \\
\hline & & Metelasmus pseudopterus ${ }^{c}$ & 3 & 0.25 \\
\hline \multirow[t]{4}{*}{ Anoura caudifera } & 12 & Anastrebla caudiferae ${ }^{d}$ & 13 & 1.08 \\
\hline & & Trichobius tiptoni & 8 & 0.66 \\
\hline & & Exastinion clovisi & 6 & 0.5 \\
\hline & & Anastrebla modestini ${ }^{d} \mathrm{~A}$ & 2 & 0.16 \\
\hline \multirow[t]{3}{*}{ Anoura geoffroyi } & 7 & Anastrebla modestini ${ }^{d}$ & 22 & 3.14 \\
\hline & & Exastinion clovisi & 11 & 1.57 \\
\hline & & Anastrebla caudiferae ${ }^{c}$ & MP & - \\
\hline Mycronicteris megalotis & 6 & Trichobius joblingi & 1 & 0.16 \\
\hline \multirow{2}{*}{ Sturnira tildae } & 6 & Megistopoda proxima $^{d}$ & 2 & 0.33 \\
\hline & & Aspidoptera falcatad & 1 & 0.16 \\
\hline Histiotus velatus & 5 & Megistopoda aranea $^{a} \mathrm{~A}$ & 1 & 0.2 \\
\hline \multirow{3}{*}{ Myotis albescens } & 5 & Anatrichobius passosi ${ }^{c}$ & 1 & 0.2 \\
\hline & & Basilia andersoni ${ }^{c} / d$ & 1 & 0.2 \\
\hline & & Basilia sp. & 1 & 0.2 \\
\hline Glossophaga soricina & 3 & Anastrebla caudiferae $b / d$ & 1 & 0.33 \\
\hline Platyrrinus lineatus & 3 & Paratrichobius longicrus & 5 & 1.66 \\
\hline Molossops neglectus & 2 & Non-infested & 0 & 0 \\
\hline Myotis levis & 1 & Anatrichobius passosi ${ }^{c}$ & 1 & 1 \\
\hline Myotis riparius & 1 & Non-infested & 0 & 0 \\
\hline Eptesicus diminutus & 1 & Non-infested & 0 & 0 \\
\hline
\end{tabular}

$a, b, c$ : new record of the bat fly species for the host, divided in three categories: new record for $a$ family, $b$ genera, and $c$ species; $d$ : new record of the bat fly species for the state of São Paulo; $e$ : new record of the bat fly species for South America; MP: misplaced material; A: accidental or transient record. 
For the Nycteribiidae, a new occurrence of Basilia andersoni Peterson \& Maa, 1970 on Myotis albescens was recorded. This fly had only been recorded on $M$. nigricans and E. brasiliensis (Graciolli \& Carvalho 2001a).

There were also records considered to be accidental or transient (Table I), in which the parasite remains for a short period of time on a non-natural host. These occurrences can be related to several factors such as the collecting method for the bats or the proximity of the shelter areas for the different bat species. Graciolli and Carvalho (2001b) observed a Megistopoda proxima bat fly abandoning the host and moving along the mist-net.

A shelter shared by more than one bat species can be another cause for the occurrence of accidental or transitory parasitism. Bertola et al. (2003) observed 6 different species of bats at Gruta do Varzeão (Varzeão Cave, state of Paraná), most of state which were infested by $T$. dugesioides, including $M$. nigricans. The occurrence of this bat fly on M. nigricans was considered accidental or transient since the number of parasites was low and $T$. dugesioides rarely occurs on this host.

The occurrence of Joblingia (Dybas \& Wenzel 1947) is the first record for Brazil. According to Guerrero (1995b), this genus is restricted to Central America, being found only in Guatemala, Costa Rica, and mountain areas of Panama. The collected specimens belong to a new species that is being described by Gustavo Graciolli (Universidade Federal do Paraná) and Patrícia B Bertola (Universidade de São Paulo).

The distribution range was extended to the state of São Paulo for the following species (Table I): Trichobius tiptoni Wenzel, 1976 (known from Minas Gerais, Paraná, Rio Grande do Sul), T. furmani Wenzel, 1966 (Distrito Federal, Paraná), Megistopoda proxima (Séguy, 1926) (Pará, Distrito Federal, Minas Gerais, Rio de Janeiro, Paraná, Santa Catarina, Rio Grande do Sul), Aspidoptera falcata Wenzel, 1976 (Pará, Minas Gerais, Paraná), Anastrebla caudiferae Wenzel, 1976 (Paraná, Santa Catarina, Rio Grande do Sul), A. modestini Wenzel, 1966 (Minas Gerais, Paraná, Rio Grande do Sul) and Basilia andersoni Peterson \& Maa, 1970 (Paraná). These extensions are associated to the increase of sampling in each region, and the fact that the distribution range of many species included the state of São Paulo was expected.

Specificity - Seven cases of parasite-host specificity were recorded, including the occurrence of the new species of Joblingia on Myotis ruber (Geoffroy, 1806). Wenzel et al. (1966) recorded Joblingia schmidti Dybas \& Wenzel, 1945 as being restricted to the genus Myotis Kaup, 1839.

Other species of Streblidae and Nycteribiidae were restricted to one host genus, such as A. falcata on Sturnira, Metelasmus pseudopterus (Coquellett, 1907) on Artibeus, Exastinion clovisi (Pessôa \& Guimarães 1937) and Anastrebla modestini on Anoura and Anatrichobius passosi (Graciolli 2003) on Myotis. Basilia was restricted to two species of the genus Myotis: M. albescens and M. nigricans (Table I).

The presence of more than one bat fly species on the same host was also verified (Table II). S. lilium was the species that presented the highest number of established infracommunities, with five associations presenting two

TABLE II

Numbers of hosts infested by more than one species of bat fly and respective percentage in relation to the total number of infested hosts (n) at Parque Estadual da Cantareira, São Paulo, February, 2000 to January, 2001

\begin{tabular}{|c|c|c|}
\hline Host/bat fly & $\mathrm{Nr}$ & $\%$ \\
\hline \multicolumn{3}{|l|}{ Sturnira lilium (n 80) } \\
\hline Megistopoda proxima + Trichobius phillostomae & 1 & 1.25 \\
\hline Megistopoda proxima + Trichobius furmani & 1 & 1.25 \\
\hline Megistopoda proxima + Aspidoptera falcata & 1 & 1.25 \\
\hline Megistopoda proxima + Paratrichobius longicrus & 2 & 2.5 \\
\hline \multicolumn{3}{|l|}{ Sturnira tildae (n 3) } \\
\hline Megistopoda proxima + Aspidoptera falcata & 1 & 33.3 \\
\hline \multicolumn{3}{|l|}{ Carollia perspicillata (n 30$)$} \\
\hline Trichobius joblingi + Paraeuctenodes similis & 10 & 33.3 \\
\hline Trichobius joblingi + Paraeuctenodes similis + Strebla guajiro & 1 & 3.33 \\
\hline Trichobius joblingi + Trichobius sp. + Paraeuctenodes similis & 1 & 3.33 \\
\hline \multicolumn{3}{|l|}{ Anoura caudifera (n 8) } \\
\hline Anastrebla caudiferae + Trichobius tiptone & 2 & 25 \\
\hline Anastrebla caudiferae + Trichobius $\mathrm{sp}$. & 1 & 12.5 \\
\hline Anastrebla caudiferae + Exastionion clovisi + Anastrebla modestini & 1 & 12.5 \\
\hline \multicolumn{3}{|l|}{ Anoura geoffroyi (n 5) } \\
\hline Exastinion clovisi + Anastrebla modestini & 3 & 60 \\
\hline \multicolumn{3}{|l|}{ Artibeus obscurus (n 6) } \\
\hline Megistopoda aranea + Metelasmus pseudopterus & 1 & 16.6 \\
\hline \multicolumn{3}{|l|}{ Myotis nigricans (n 13) } \\
\hline Basilia sp. + Megistopoda proxima & 1 & 7.7 \\
\hline
\end{tabular}


species of flies, one of them always being M. proxima. $T$. phyllostomae presented the highest number of associations (three). However, there were no exclusive species (Table II). The infracommunity composed of M. proxima and A. falcata was recorded on this host and also on $S$. tildae. The occurrence of P. longicrus on S. lilium is believed to be accidental or transient.

Three types of communities, with two to three species each, were found on C. perspicillata. The association of T. joblingi and P. similis, was observed for all infracommunities. Strebla guajiro and Trichobius sp. were considered accidental or transitory occurrences.

Three types of communities were also formed on $A$. caudifera, with Anastrebla caudiferae in all of them. There was a greater occurrence of associations with species of the genus Trichobius, however there was no preference for any species (Table II).

The occurrence of $E$. clovisi together with A. modestini was recorded on A. caudifera and A. geoffroyi. However, in A. caudifera, A. caudiferae was also associated to this infracommunity (Table II).

M. aranea and Metelasmus pseudopterus was the only association found on A. fimbriatus. This was also observed by Graciolli and Rui (2001).

Basilia sp. and $M$. proxima were found on $M$. nigricans. This association with $M$. proxima is believed to be accidental or transitory.

Infestation prevalence and intensity - Most of the streblid species presented a higher proportion of males (Table III), in accordance to the results presented by Graciolli and Rui (2001) and Linhares and Komeno (2000). Nevertheless, due to the number of specimens per species, there was no statistically significant difference in the sex ratio for most streblids, except in P. longicrus (Pvalue $=0.015$ ).
A. passosi presented a higher proportion of females. Nevertheless, this species was recently described (Graciolli 2003) and there are no after studies to allow a comparison of these data.

According to Wenzel (1976) this difference in proportion can be caused by the collecting method, since male flies are more active and more easily detected on the hosts bodies than females. Another important factor that could influence this difference is the fact that females often leave the host for larviposition (Fritz 1983). Wenzel (1976) also emphasized that there is a greater equilibrium in the sex ratios of wingless species and those with reduced wings, as recorded for E. clovisi and M. pseudopterus, species that did not present statistically significant differences between the number of males and females.

There was a positive relation between parasitism and the bats' juvenile stage $\left(\chi^{2}=4.41\right.$; alfa $\left.<5 \% \mathrm{Q}=+0.46\right)$. Since grooming is the main cause of ectoparasite mortality (Marshall 1981), the fact that this behavior is still less satisfactory for immature bats might have influenced this result. Nevertheless, some species seem to be less disturbed by the presence of parasites in the adult stage, as observed by Fritz (1983) for C. perspicillata. Marshal (1981) also associates this occurrence to morphological aspects, such as differences on epidermis thickness that might facilitate haematophagy. Komeno and Linhares (1999) observed a relationship between parasitism and the hosts juvenile stage. This fact was attributed not only to a dispersal strategy on the part of the flies, based on the assumption that the young search out new shelters to form new family nucleus, but also to deficient grooming at this developmental stage of the host.

Considering the most abundant hosts and their respective bat flies, specific differences can be observed in the relationship between host and parasite (Tables IV, V).

TABLE III

Numbers of males and females and the sex ratio of Streblidae at Parque Estadual da Cantareira, São Paulo, collected between February, 2000 and January, 2001

\begin{tabular}{lcccc}
\hline Streblidae & Males & Females & Indet. $^{a}$ & Sex ratio (M:F) \\
\hline Aspidoptera falcata & 7 & 3 & 2 & $1: 0.42$ \\
Anastrebla caudiferae & 9 & 6 & 0 & $1: 0.66$ \\
Anastrebla modestini & 16 & 10 & 3 & $1: 0.62$ \\
Anatrichobius passosi & 2 & 5 & 0 & $1: 2.5$ \\
Exastinion clovisi & 9 & 8 & 0 & $1: 0.88$ \\
Joblingia sp. & 2 & 0 & 0 & - \\
Megistopoda aranea & 13 & 8 & 1 & $1: 0.61$ \\
Megistopoda proxima & 53 & 50 & 3 & $1: 0.94$ \\
Metelasmus pseudopterus & 2 & 3 & 0 & $1: 1.5$ \\
Paratrichobius longicrus & 45 & 24 & 5 & $1: 0.53$ \\
Paraeuctenodes similis & 19 & 9 & 3 & $1: 0.47$ \\
Strebla guajiro & 0 & 2 & 0 & - \\
Trichobius dugesioides & 3 & 0 & 0 & - \\
Trichobius furmani & 0 & 1 & 0 & - \\
Trichobius joblingi & 35 & 3 & 2 & $1: 0.62$ \\
Trichobius tiptoni & 7 & 8 & 1 & $1: 0.42$ \\
Trichobius phillostomae & 10 & 0 & 0.8 \\
Trichobius sp. & 2 & 3 & - \\
\hline S: & & 0 & \\
\hline
\end{tabular}

$\bar{a}$ : specimens recorded as undetermined due to the difficulties in visualizing the genitalia and not used in the determination of the sex ratio. 
In the relationship between $S$. lilium and $M$. proxima, a prevalence of $27 \%$ was found, slightly smaller than that found by Komeno and Linhares (1999) in Minas Gerais (34\%). There was no statistical difference between the proportion of infested males and females. There was a prefer- ence of the flies for the juvenile stages in both sexes, but mainly in the males, with statistically significant results (males $\chi^{2}=10.44 ; \mathrm{P}=0.005$ - females $\chi^{2}=9.46 ; \mathrm{P}=0.051$ ). The same was observed for the mean abundance. The mean intensity indicated a preference for females, with a

\section{TABLE IV}

Prevalences $(\%)$ of bat flies in relation to sex and reproductive stage of the most abundant hosts at Parque Estadual da Cantareira, São Paulo, February, 2000 to January, 2001

\begin{tabular}{llccc}
\hline $\begin{array}{l}\text { Host } \\
\text { Bat fly }\end{array}$ & \multicolumn{1}{c}{$\begin{array}{c}\text { Sturnira lilium } \\
\text { Megistropoda proxima }\end{array}$} & $\begin{array}{c}\text { Artibeus lituratus } \\
\text { Paratrichobius longicrus }\end{array}$ & $\begin{array}{c}\text { Carollia perspicillata } \\
\text { Trichobius joblingi }\end{array}$ \\
\hline Male & Juvenile & $55(11)$ & $20(1)$ & $33(1)$ \\
& Adult TA & $32.1(18)$ & $26(6)$ & $35.7(5)$ \\
& Adult TE & $13.8(5)$ & $24(6)$ & $28.5(2)$ \\
& Total & $13.7(34)$ & $12.7(13)$ & $17.4(8)$ \\
Female & Juvenile & $50(11)$ & $25(4)$ & $80(4)$ \\
& Adult & $19.6(10)$ & $50(6)$ & $50(7)$ \\
& Lactant & $20(5)$ & $37.5(3)$ & $33.3(2)$ \\
& Pregnant & $14.2(2)$ & $50(2)$ & 0 \\
& Post-Lactant & $22.7(5)$ & $66.6(6)$ & 0 \\
& Total & $13.3(33)$ & $20.5(21)$ & $25.5(12)$ \\
\hline Global ratio & & $27.1(67)$ & $33.3(34)$ & $42.5(20)$ \\
\hline
\end{tabular}

TA: abdominal testes; TE: scrotum testes; Adult: nonestrus female (non reproductive stage). The total number of captured bat flies is indicated in parenthesis.

\section{TABLE V}

Mean abundances and mean intensities of bat flies in relation to sex and reproductive stage of the most abudant hosts at Parque Estadual da Cantareira, São Paulo, February, 2000 to January, 2001

\begin{tabular}{|c|c|c|c|c|c|c|c|}
\hline \multirow{3}{*}{$\begin{array}{l}\text { Host } \\
\text { Bat fly }\end{array}$} & & \multirow{2}{*}{\multicolumn{2}{|c|}{$\begin{array}{c}\text { Sturnira lilium } \\
\text { Megistropoda proxima }\end{array}$}} & \multirow{2}{*}{\multicolumn{2}{|c|}{$\begin{array}{c}\text { Artibeus lituratus } \\
\text { Paratrichobius longicrus }\end{array}$}} & \multirow{2}{*}{\multicolumn{2}{|c|}{$\begin{array}{c}\text { Carollia perspicillata } \\
\text { Trichobius joblingi }\end{array}$}} \\
\hline & & & & & & & \\
\hline & & $\mathrm{AM}$ & IM & $\mathrm{AM}$ & IM & AM & IM \\
\hline Male & $\begin{array}{l}\text { Juvenile } \\
\text { Adult TA } \\
\text { Adult TE } \\
\text { Total }\end{array}$ & $\begin{array}{c}1 \\
0.4 \\
0.3 \\
0.2\end{array}$ & $\begin{array}{l}1.9 \\
1.4 \\
2.2 \\
1.27\end{array}$ & $\begin{array}{l}0.4 \\
0.34 \\
0.28 \\
0.1\end{array}$ & $\begin{array}{l}2.0 \\
1.3 \\
1.1 \\
2.1\end{array}$ & $\begin{array}{l}1.0 \\
1.0 \\
1.0 \\
0.4\end{array}$ & $\begin{array}{l}1.5 \\
2.8 \\
2.8 \\
3.0\end{array}$ \\
\hline Female & $\begin{array}{l}\text { Juvenile } \\
\text { Adult } \\
\text { Lactant } \\
\text { Pregnant } \\
\text { Post-Lactant } \\
\text { Total }\end{array}$ & $\begin{array}{l}0.5 \\
0.23 \\
0.24 \\
0.1 \\
0.4 \\
0.1\end{array}$ & $\begin{array}{l}1.2 \\
1.2 \\
1.2 \\
1.0 \\
1.8 \\
1.67\end{array}$ & $\begin{array}{l}2.0 \\
1.0 \\
1.0 \\
2.2 \\
1.3 \\
0.4\end{array}$ & $\begin{array}{l}1.0 \\
2.0 \\
2.6 \\
4.5 \\
1.5 \\
1.3\end{array}$ & $\begin{array}{l}1.6 \\
1.6 \\
1.6 \\
0.0 \\
0.0 \\
0.8\end{array}$ & $\begin{array}{l}2.0 \\
3.3 \\
5.0 \\
0.0 \\
0.0 \\
2.62\end{array}$ \\
\hline \multicolumn{2}{|c|}{ Global ratio } & 0.4 & 1.04 & 0.6 & 1.82 & 1.2 & 2.85 \\
\hline
\end{tabular}

AM: mean abundance; IM: mean intensity; TA: abdominal testes; TE: scrotum testes; Adult: nonestrus female (non reproductive stage).

TABLE VI

Bat flies infected by fungi, collected on bats from Parque Estadual da Cantareira, São Paulo, SP, February, 2000 to January, 2001

\begin{tabular}{lcccr}
\hline Bat fly & Total number & $\begin{array}{c}\text { Number of } \\
\text { infested specimens }\end{array}$ & Prevalence (\%) & Confidence interval (95\%) \\
\hline Megistopoda proxima & 106 & 18 & 17 & $(10.4-25.5)$ \\
Anatrichobius passosi & 6 & 3 & 50 & $(11.8-88.1)$ \\
Megistopoda aranea & 22 & 2 & 9 & $(1.1-29.2)$ \\
Exastinion clovisi & 15 & 2 & 13.3 & $(1.7-40.5)$ \\
Paratrichobius longicrus & 68 & 1 & 1.5 & $(0.04-7.9)$ \\
\hline Total & 217 & 26 & 12 & $(8.0-17.0)$ \\
\hline
\end{tabular}


greater value for the post-lactant ones. Among the males there was a preference for adults with scrotal testes.

In the relationship between $A$. lituratus and $P$. longicrus, the prevalence for this species was of $33.3 \%$ in this study, below that of $37 \%$ found by Graciolli and Rui (2001). The prevalence was higher for adult females, with a preference for post-lactant females. Contrary to the prevalence, the results of the mean abundance and mean intensity were higher ( 0.6 and 1.82 respectively) than those found by Graciolli and Rui (2001) (0.3-0.8). An analysis of the data for the sex of the host showed higher values of mean abundance for females and a mean intensity for males. Between the reproductive stages there was a noticeable value in the abundance and average intensity for pregnant females.

In the relationship between $C$. perspicillata and $T$. joblingi, a prevalence of $42.5 \%$ was obtained. Compared to the study of Komeno and Linhares (1999) in Minas Gerais with 66\%, Wenzel et al. (1966) in Panama and Wenzel (1976) in Venezuela, who registered values above $60 \%$, the prevalence obtained in this study was low. In the prevalence by sex, there was a preference for females, contrary to the studies of Komeno and Linhares (1999) with $25.5 \%$ and $17.4 \%$ respectively. For the mean abundance there was a preference for females, with the same value obtained both for age and reproductive stages. For the average intensity, there was a preference for males, the values being the same for those with abdominal tests and scrotum tests. However, the values obtained for adult females in estrus and in lactation were notable.

Hyperparasitism - Fungi of the order Laboulbeniales order are frequently found infesting ectoparasites (Marshall 1981). According to Marshall (1981), there are three genera that infest bat flies: Antrrohynchus in the Nycteribiidae and Gloeamdromyces and Nycteromyces in the Streblidae.

The majority of the Nycteromyces species do not penetrate the tegument, thus causing little damage to the flies (Benjamin 1971, Blackwell 1980). However, species of Antrrorhynchus and Gloeamdromyces penetrate the tegument, forming ramifications inside the body cavities.

The first study mentioning the occurrence of fungi on bat flies of the New World (Fritz 1983), deals with the biology and ecology of bat flies on Carollia bats. Fritz (1983) believed that, depending on the body region affected, the presence of fungi on bat flies can cause problems, such as difficulty of locomotion, when located on the legs and near the wings.

During the identification of the flies, the presence of these fungi was observed. Of the 18 species of Streblidae, five were infected by fungi, totaling 26 infected specimens. There was no hyperparasitism on Basilia.

The fungi presented mycelium with 1 to 28 hyphae in the same spot. These were distributed over one or more body parts of the same fly. A preference of the fungi for the soft body parts, such as the abdomen (65\%), was observed. Other parts of the body, such as the lateral regions $(10.3 \%)$, antero-dorsal part of the thorax $(6.9 \%)$, femur $(6.9 \%)$ and theca $(3.4 \%)$ were also infested by fungi. Males were more infected $(77 \%)$ than females $(23 \%)$, and the fungi showed a preference for the ventral abdominal region of wales (50\% of the total of 20 infected specimens). Of these, the majority ( 7 specimens) presented hyphae near the aedeagus. In females, the preference was for the dorsal region of the abdomen (4 of a total of 6 specimens). Of these, 2 presented hyphae near the genitalia.

The total hyperparasitism rates recorded in this study were low, representing only $6 \%$ of the total of the captured specimens. This low level of infection was also observed by Blackwell (1980) in nycteribiids of the Old World.

The data on the location of the fungi on the bat fly's body, as well as the relationship between the infested region and the host's sex, also corroborates Blackwell's results (1980a). Marshall (1981) believed that this preference for infestation in the regions near the genitalia constitutes a dispersal strategy of the fungi, due to the close contact during mating.

\section{ACKNOWLEDGEMENTS}

To Kátia Mazzei, director of the Parque Estadual da Cantareira, for colletion permission and logistical support during the field work. To all the trainees at the Laboratório de Biodiversidade of Uniban for their unvaluable participation in the field work.

\section{REFERENCES}

Allen GM 1967. The parasites of bats. Bats. Museum of Comparative Zoology, $368 \mathrm{pp}$.

Autino AG, Claps GL, Barquez RM 1999. Insectos ectoparasitos de murciélagos de las Yungas de la Argentina. Acta Zool Mex 78: 119-169.

Autino AG, Claps GL, Barquez RM 2000. Nuevos registros de Diptera (Nycteribiidae) y Siphonaptera (Ischnopsyllidae) de Chiroptera (Vespertilionidae) de la Argentina. Bol Ent Venezolana 15: 109-112.

Autino AG, Claps GL, Bertolini MP 1998. Primeiros registros de insectos ectoparasitos (Diptero, Streblidae) de murciélagos Del Parque Nacional Iguazú, Misiones, Argentina. Revta Bras Ent 42: 59-63.

Barquez RM, Claps GL, Autino AG 1991. Nuevos registros de ectoparasitas de murcielagos en el noroeste argentino. Revta Soc Ent Argentina 49: 78-102.

Benjamin RK 1971. Introduction and supplement to Roland Thaxter's contribution towards a monograph of the Laboulbeniceae. Biblthca Mycologia 30: 1-155.

Bequaret J 1940. Moscas parasitas pupiparas de Colombia y Panama. Acad Colombiana Cienc Exac Fis Nat 3: 414-418.

Bertola PB, Aires CC, Chaves ME, Pinto-Da-Rocha R 2003. Morcegos e dípteros associados da Gruta do Varzeão (Doutor Ulisses, PR). In II Congresso de Mastozoologia, Belo Horizonte, MG, Abstracts.

Blackwell M 1980. Incidence, host specificity, distribution, and morphological variation in Arthrorhynchus nycteribiae and A. eucampsupodae (Laboulbeniomycetes). Mycologia 72: 143-158.

Bush AO, Lafferty KD, Lotz JM, Shotak AW 1997. J Parasitol 83: 575-583.

Claps GL, Autino AG, Barquez RM 1992. Nuevas citas de dipteros ectoparasitos (Nycteribiidae) para murcielagos de 
la Argentina. Revta Soc Ent Argentina 50: 88.

Fritz GN 1983. Biology and ecology of bat flies (Diptera: Streblidae) on bats in the genus Carollia. J Med Ent 20: 110.

Graciolli G 2003. Nova espécie de Anatrichobius Wenzel, 1966 (Diptera, Streblidae) do Brasil meridional. Revta Bras Ent 47: 55-58.

Graciolli G, Carvalho CJB 2001a. Moscas ectoparasitas (Diptera, Hippoboscoidea, Nycterybiidae) de morcegos (Mammalia: Chiroptera) do Estado do Paraná, Brasil. I. Basilia, taxonomia e chave pictórica para as espécies. Revta Bras Zool 18: 907-960.

Graciolli G, Carvalho CJB 2001b. Moscas ectoparasitas (Diptera, Hippoboscoidea, Nycterybiidae) de morcegos (Mammalia: Chiroptera) do Estado do Paraná, Brasil. II. Streblidae. Chave pictórica para os gêneros e espécies. Revta Bras Zool 18: 907-960

Graciolli G, Coelho DC 2001. Streblidae (Diptera, Hippobovoidea) sobre morcegos filostomídeos (Chiroptera, Phyllostomidae) em cavernas do Distrito Federal Brasil. Revta Bras Zool 18: 965-970.

Graciolli G, Linardi PM 2002. Some Streblidae and Nycteribiidae (Diptera: Hippoboscoidea) from Maracá Island, Roraima, Brazil. Mem Inst Oswaldo Cruz, 97: 139-141.

Graciolli G, Rui AM 2001. Streblidae (Diptera, Hippobocoidea) em morcegos (Chiroptera, Phyllostomidae) no nordeste do Rio Grande do Sul, Brasil. Iheringia Zool 90: 85-92.

Guerrero R 1994a. Catalogo de los Streblidae (Diptera: Pupipara) Parasitos de Murciélagos (Mammalia:Chiroptera) del Nuevo Mundo.II. Los grupos: pallidus, caecus, major, uniformis y longipes del gênero Trichobius Gervais, 1844. Acta Biol Venez 9: 1-18.

Guerrero R 1994b. Catalogo de los Streblidae (Diptera: Pupipara) parasitos de murciélagos (Mammalia:Chiroptera) del Nuevo Mundo. IV. Trichobiinae com alas desarrolladas. Bol Ent Venez 9: 161-192.

Guerrero R 1995a. Catalogo de los Streblidae (Diptera: Pupipara) parasitos de murciélagos (Mammalia:Chiroptera) del Nuevo Mundo. III. Los gupos: dugesii, dunni y phyllostomae del Genero Trichobius Gervais, 1844. Acta Biol Venez 15: 127.

Guerrero R 1995b. Catalogo de los Streblidae (Diptera: Pupipara) parasitos de murciélagos (Mammalia:Chiroptera) del Nuevo Mundo. V. Trichobiinae con alas reducidas o ausentes y miscelaneos. Acta Biol Venez 10: 135-160.

Guimarães LR, D’Andretta MA 1956. Nycteribiidae (Diptera) do Novo Mundo. Arq Zool 10: 1-184.

Komeno CA, Linhares AX 1999. Bat flies parasitic on some phyllostomid bats in Southeastern Brazil: parasitism. Rates and host-parasite relantionships. Mem Inst Oswaldo Cruz. 94: 151-156.

Linhares AX, Komeno CA 2000. Trichobius joblingi, Aspidoptera falcata and Megistopoda proxima (Diptera: Streblidae) parasitic on Carollia perspicillata and Sturnira lilium (Chiroptera: Phyllostomidae) in Southestern Brazil: sex ratios, seasonality, host site preference, and effect of parasitism on the host. J Parasitol 86: 167-170.

Marshall AG 1981. Ecology of Ectoparasites Insects, Academic Press, London.

Marshall AG 1982. Ecology of insects ectoparasitic on bats. In JH Kunz, Ecology of Bats, Plenum Publishing, London, p. 369-401.

Negreiros OC, Carvalho CT, Cesar SF, Duarte FR, Deshler WO, Thelen KD 1974. Manual de manejo para o Parque Estadual da Cantareira. Bol Técnico 10: 1-58.

Peterson BV, Wenzel RL 1987. Nycteribiidae. In JF Mcalpine, BV Peterson, GE Shewell, HJ Teskey, JR Vockeroth, DM Wood (eds), Manual of Neartics Diptera, Vol. 2, Minister of Supply and Services, Ottawa, Monograph 28, p. 12831301.

Rizzini CT. 1979. Tratado Fitogeográfico do Brasil, Aspectos Sociológicos e Florísticos, Universidade de São Paulo, São Paulo, 374 pp.

Wenzel RL 1976. The Streblidae bat flies of Venezuela (Diptera: Streblidae), Brigham Young Univ Sci Bull, Biol Ser, 20: 1177.

Wenzel RL, Tipton VJ, Kiewlicz A 1966. The Streblid bat flies of Panama (Diptera: Calyptera: Streblidae). In RL Wenzel \& VJ Tipton (eds), Ectoparasites of Panama, Field Mus Nat Hist, Chicago, p. 405-675.

Whitaker Jr JO 1988. Collecting and preserving ectoparasites for ecological study. In JH Kunz, Ecological and Behavioral Methods for the Study of Bats, Smithsonian Institution Press, Washington, p. 459-474. 